\title{
サステナブルな地理空間情報流通に向けた関係 者のインセンティブと負担に関する実証研究
}

\author{
関本 義秀 1 ・薄井 智貴 2 - 山田 晴利 $3 \cdot$ 今井 龍一 4 ・山口 章平 5 - 柴崎 亮介 6 \\ 1正会員 東京大学特任准教授 空間情報科学研究センター（†277-8568 千葉県柏市柏の葉5-1-5） \\ E-mail: sekimoto@csis.u-tokyo.ac.jp \\ 2正会員 東京大学特任助教 空間情報科学研究センター（テ277-8568 千葉県柏市柏の葉5-1-5） \\ E-mail: usui@csis.u-tokyo.ac.jp \\ 3正会員 東京大学特任教授 空間情報科学研究センター（干153-8505 東京都目黒区駒場4-6-1） \\ E-mail: yamada.hal@csis.u-tokyo.ac.jp \\ 4正会員 国土技術政策総合研究所研究官（†305-0804 茨城県つくば市旭1番地） \\ E-mail: imai-r92ta@nilim.go.jp \\ 5非会員＼cjkstart株式会社建設技術研究所東京本社情報部（干103-8430 東京都中央区日本橋浜町3-21-1） \\ E-mail: s-yamaguchi@ctie.co.jp \\ 6正会員 東京大学教授 空間情報科学研究センター（テ277-8568 千葉県柏市柏の葉5-1-5） \\ E-mail: shiba@csis.u-tokyo.ac.jp
}

\begin{abstract}
2007年に成立した地理空間情報活用推進基本法を契機に，地理空間情報を活用したサービスは日々進展 を遂げている，その一方で，国土あるいは公共施設等のベースとなる情報は，データ提供主体ごとに，形 式だけでなく，入手条件や権利関係，更新頻度等が多様であり，利用者側からみるとデータ収集は手間の かかる作業である，従って，本研究は，公共事業等で作成された地理空間情報の収集・配信・利活用等に 関わる円滑な流通環境の実現を目的とする「地理空間情報流通実験コンソーシアム」の活動を通じ，デー タ利用者のニーズ, データ保有者の制約等を把握し, 関係者の役割分担を提案する.また, 実証実験とし て，広範なデータ収集活動，データ共有を効率的に実現するシステムの構築と運用，利用者・保有者の意 見集約を行い，流通の仕組みの妥当性を評価した。
\end{abstract}

Key Words : geospatial information, data collection and distribution, experimental study

\section{1. はじめに}

2007年に成立した地理空間情報活用推進基本法を契機 に，地理空間情報を活用し，防災，店舗案内，土地取引， 環境保護活動等の地域の暮らしのサポートや，安全・安 心，低炭素社会等の社会全体の目標実現などと密接に関 連する，様々なICTを活用したアプリケーションサービ スが日々進展を遂げている注1).

一方，地理空間情報としての様々な国土あるいは公 共施設等のベースとなる情報は，電子行政の進展に伴い， 国や地方自治体等からホームページや情報公開請求等を 通じて徐々に提供されるようになってきてはいるものの, 個別のデータごと，あるいはデータ提供団体ごとに，デ 一タ形式だけなく, データ入手条件や権利関係，更新頻 度等は多様である。
これらデータの利活用を一層促進していくためには, 利用者である民間企業や研究機関等を念頭に，それぞれ のデータの特性を踏まえつつ, 可能な範囲で最大限, 流 通・加工がしやすいように，データの品質を明らかにし， 集約を進める仕組みを確立することが重要である.

しかしデータを保持する主体は国や各地方自治体等, 大変多岐にわたり, また, データの加工やシステムの改 修はコス卜負担もかかるため, 自らのインセンティブを 予想しにくい初期の段階から, 全体の集約が進むように 各主体が協力するといった理想的な状況を期待すること は難しい，そこで，オープンな枠組みの中で上述のデー 夕流通の仕組みを現実に照らし合わせて微調整し, 徐々 に成長をしていけるような実証研究的なアプローチも必 要である.

既存のデータ流通に関連する取組みとして，政府を 
中心とした地理情報クリアリングハウス (http://www.spat.nilim.go.jp/home/) ${ }^{12) 2}$ により, 省内のデー 夕集約を目指し，2011年8月現在で150万件弱の登録が行 われるようになったが，基本的には，メタデータのみで あり，オリジナルデータ（以下，「生データ」と呼 ぶ.）そのものは入手できない.

そもそもこうした活動は，最近では「新たな公」注2)と いう流れもあるように，利用者でもある産学サイドが一 翼を担ってもおかしくない面があった。しかし， CALS/ECや建設情報統合化に関する研究（例えば佐藤ら (2006） 3)）は多数あるものの，ある一断面の技術的検 討が多く，なぜデータ集約あるいは流通がうまくいかな いか，データ流通そのものへの負担感やインセンティブ に関する研究は今井ら（2008）出などで散見される程度 であった。

折りしも，地理空間情報活用推進基本法成立後，政府 から2010年に「地理空間情報の二次利用促進に関するガ イドライン 注3)」が出される等, データ流通の活性化を念 頭に置いた取組みが始まりつつある. また，アメリカの オバマ政権では，2009年から「オープンガバメント」と いう構想の一環で，政府からデータをマシンリーダブル な形で無償提供を行う"DATA.gov"（http://www.data.gov） という取組みも始まっており，流通への環境は整いつつ ある.さらにWebの開発者の一人であるティム・バーナ ーズ・リーも2010年には"The year open data went worldwide" として，行政機関による生データ提供の必要性を提唱し て注4，世界的なムーブメントになってきた。

従って，本研究は，地理空間情報の収集・配信・利活 用等に関わる円滑な流通環境の実現を目的として，デー タ利用者のニーズ，データ保有者の制約等の課題を把握 するとともに，実際に広くデータ収集活動を行い，デー タ共有を効率的に実現するためのシステムの構築・運用 を行い，実際に利用者，保有者の意見をまとめ，その妥 当性を評価するという一連の実証研究を行うものである。 具体的には，2章で地理空間情報の二ーズや提供側の実 態や課題について, 調查結果をもとに把握し，3章では 流通のための仕組み，役割分担の提案を行う。また， 4 章では実証実験として実際にデータの収集，ユーザーの 募集からシステム構築，データの利用状況調査，アンケ 一ト，利活用のマッシュアップコンテストなどを行った 結果を示し，それの考察や残された課題を明確にする. そして最後に5章でまとめを行う。

本研究は主に, 東京大学空間情報科学研究センターが, 2009 年9 月～2011年3月までの約1年半の間，産官学の関 係機関が連携した「地理空間情報流通実験コンソーシア ム (http://parma.csis.u-tokyo.ac.jp)」の活動成果であり，い くつかの内容についてはすでに論文として発表している. 具体的には産業界のニーズをまとめた杉森ら（2009）5，
システムの構築をまとめた薄井らの，データの詳細を記 した活動報告注5)，道路関係データの詳細なニーズや提供 実態”，道路関係データの位置特定手法の開発 ${ }^{8)}$ ，構造化 データとしてのLinkedDataとの関連をまとめだものがあ るが，本報告は，未発表の成果を含め，標記コンソーシ アムが終了した後に加筆・修正し，全体をまとめたもの である．こうした様々な主体の異なる種類のデータを全 国規模で収集し，多数のユーザーで共有した例は今まで なく，大きなインパクトを与えたと言える.

\section{2. 地理空間情報のニーズと課題意識}

\section{(1) 利用の二ーズ}

ここでは，流通の仕組みを検討寸るにあたり，利用者 のニーズとして2008年9〜10月に業界団体を通じて民間 企業に送付し回答があった325件のアンケート結果をま とめた杉森ら（2009）古を簡単に紹介する（表-1）。具 体的には，国土交通省や地方自治体の持つ地盤情報や気 象情報等，105の情報項目から積極的にダウンロードし て利用（加工・編集・統計処理等）したいもの上位10個 を選び，1件の回答ごとに，二ーズの高い順に10点〜1点 でスコア化し，合計した．その結果，埋設物，ボーリン グ情報, 基準点, 空中写真画像等のスコアが高かった.

これらスコアが高い地物は，現在，Web等で一部閲覧 することはできても生データそのものの提供が行われて いないため収集しにくく，そうしたものへのニーズが高 いことが判明した。 ここから言えることは，公開してい るデータ閲覧サイトの範囲でポータルサイトを構築する ということよりは，生データが未提供なものを，何らか の形で提供していくことを促進することへのニーズが高 いということである.

\section{（2）データ流通に対する課題意識}

また，同アンケートでは，利用者側から見たデータ流 通に対する課題も聞いた．表-2のように，各データの更 新頻度やさらに詳細な情報や継続的に更新されていくか などを知りたい，という意見が多かった．各データに対 する基本的な情報はある程度，利用者側もすでに知って いるものの，継続的・安定的に商業利用をしたいという 観点からは，更新時期，作成時期等の品質に関する担保 という点を重視していることがわかる.

ただし，現実的には，各データ提供者が更新時期や作 成時期あるいはその他の情報を同じ品質で提供していく ことは簡単でないため, データ流通の場を管理する立場 が必要なことも示唆している. 
表-1＼cjkstart利用ニーズの高い地理空間情報 ( ${ }^{(5)}$ の抜粋)

\begin{tabular}{l|l|l}
\hline 順位 & 情報項目 & スコア \\
\hline 1 & 埋設物情報 & 1,235 \\
\hline 2 & ボーリング情報 (柱状図や土質試験結果) & 1,151 \\
\hline 3 & 基淮点 (位置, 点の記) & 1,080 \\
\hline 4 & 空中写真画像 & 1,072 \\
\hline 5 & 交通量データ & 728 \\
\hline 6 & 道路ネットワークデータ & 638 \\
\hline 7 & 土地利用基本計画図 & 414 \\
\hline 8 & レーザプロファイラ等による微地形データ & 390 \\
\hline 9 & 代ードマップ (洪水, 内水, 高潮, 津波, 土 & 337 \\
\hline 10 & 砂災害, 火山) & 32 \\
\hline
\end{tabular}

表-2 データ流通に対する課題意識（アンケート結果）

\begin{tabular}{|c|c|c|}
\hline チェック項目 & 回答数 & 率 \\
\hline 情報の更新頻度がわからない & 189 & $58 \%$ \\
\hline もつと詳細な情報を入手したいことがある & 181 & $56 \%$ \\
\hline いい作成されたデータかがわからない & 169 & $52 \%$ \\
\hline $\begin{array}{l}\text { 利用する情報が継続的に更新され続けていくの } \\
\text { かを知りたい }\end{array}$ & 170 & $52 \%$ \\
\hline $\begin{array}{l}\text { 情報を利用する際の制約条件（手続きや権利な } \\
\text { ど）の有無がわからない }\end{array}$ & 143 & $44 \%$ \\
\hline 情報が有償か無償なのかがわからない & 133 & $41 \%$ \\
\hline 情報の入手方法がわからない & 101 & $31 \%$ \\
\hline 情報の作成者や提供者がわからない & 65 & $20 \%$ \\
\hline その他（自由記入） & - & - \\
\hline
\end{tabular}

\section{（3）行政が保持する情報の提供状況}

一方，行政側は保持する情報をどの程度提供できてい るだろうか．2010年4〜 5月に全都道府県の道路，林政， 農政部門に図面関連の「データ提供頻度」「データ管理 に関する負担感」「データ流通実験への関心」等を聞い た結果が図-1である。

a)の提供頻度について，道路や林政では，年間50回以 上が有効回答の2〜3割程度あり，b)のデータ管理に関す る負担感でも同様に，「データ管理，更新や問合せ対応 が手間」という回答が有効回答の2〜3割程度存在し, 潜 在的な負担感があることも明らかになった，一方で，農 政部門は農地関連の図面を都道府県が直接管理していな い. 従って, 他の2部門に比べ，回答なしがかなり多く， 回答があっても提供頻度は低く, あまり負担感もないこ とがわかった。

なお，c)では我々が行っている流通実験の概要・趣旨 を記載した書類を参考として添付し, 直接の説明等は行 わなかったところ，「ふつう」という回答が多く, 課題 意識を共有できたところはあまり多くなかった。

\section{3. データ流通の制度設計}

\section{(1) 保有者，利用者，管理者の役割分担}

こうした背景を踏まえ，ここでは生データ流通の仕組 みを提案する.さほぼ複雑ではなく, シンプルなもので

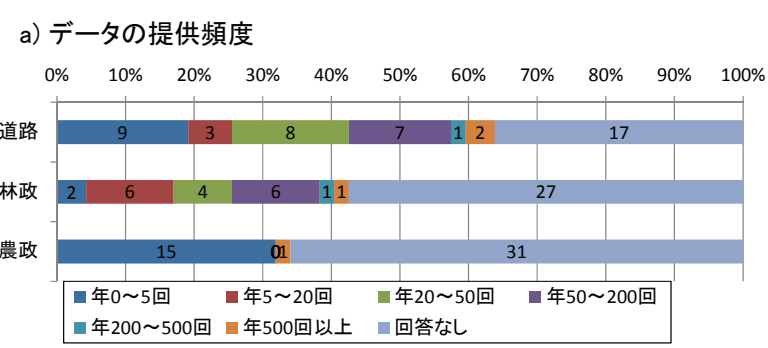

b) データ管理に関する負担感

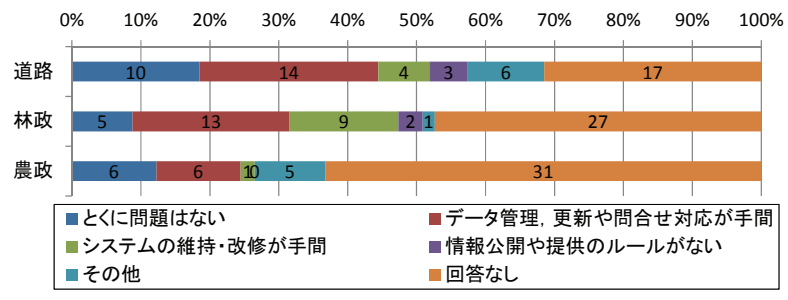

c) 流通実験への興味

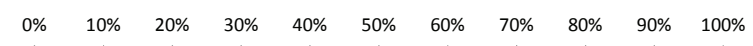

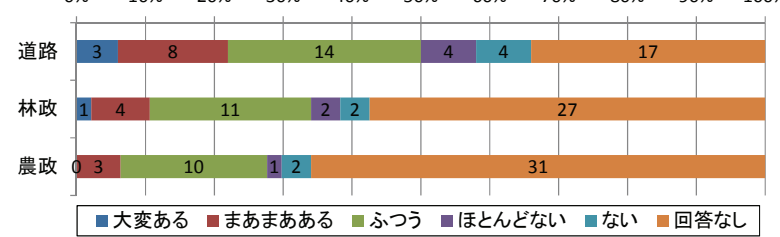

図-1＼cjkstart情報の提供状況（道路・林政・農政部門に関するアンケ 一下結果)

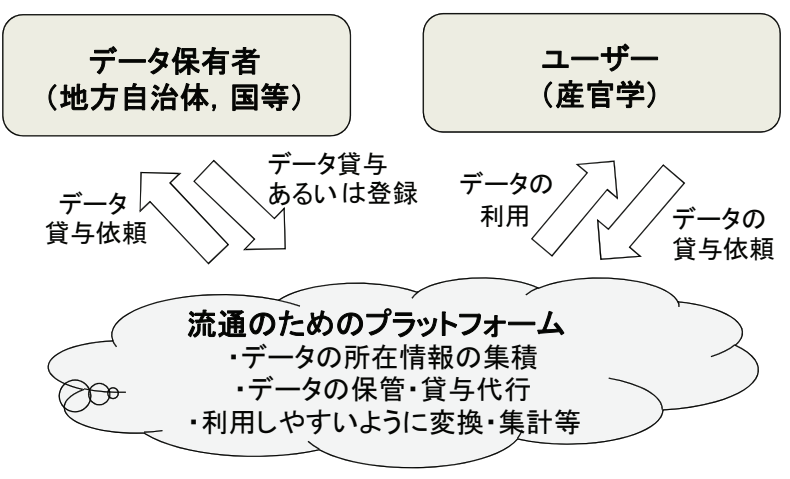

図-2 データ流通市場のイメージ

あるが，プラットフォームの管理者からデータ保有者 （地方自治体，国等）に対して，このコミュニティで共 有することを前提にしたデータ貸与依頼を行い，貸与を 許諾頂けた場合には適宜，プラットフォームに登録し， その後，IDを持つコミュニティのユーザーが検索やダウ ンロードを行える仕組みである（図-2）。

ただし，この仕組みは，2.(1)，(2)で述べたような利用者 側のリクワイヤメントは踏まえており理想的であるが, 2.(3)で述べたような提供する立場であるデー夕保有者, あるいはそれを代行する立場の管理者の負担がかなり増 えることが予想されるため, その負担低減のため以下の 点を重視した制度設計を行った。 
・ データのトレーサビリティ確保 : プラットフォーム からデータそのものをダウンロードできるのはIDを 持つユーザーのみとする．これにより「Webに対す る完全公開（不特定多数一の提供）は難しいが，ユ ーザーのトレーサビリティが確保されている範囲で の提供はできる」という選択肢を設定でき，データ 保有者側の提供に対する心理的な負担，技術的負担 を軽減できる，ただし，検索・閲覽はだれでもでき るため，一般へのアピールも可能である（もちろん， 一般へのデータ公開は妨げない）。

・ 提供時のデータ加工の不要性 : プラットフォームで は，後述の最低限のメタデータ形式は設定している が，データ保有者からの提供は保有者が持つデータ 形式を基本とし，メタデータ作成や実データの整形 はプラットフォーム側で行う。これにより，標準的 な形式等に合わないデータを提供する際には，デー 夕保有者自らが標準的な形式に合わせるための加工 費用を負担しないといけないという負担感を軽減で きる.

・ プラットフォームの中立性 : 一方，プラットフォー ム側ではメタデータ作成や実データの整形は多大な 負担になる可能性があるものの，個別組織で行うよ りは，一手に集中して行うことによる作業負担軽減
土木学会論文集F3(土木情報学), Vol. 68, No. 1, 71-83, 2012.

のメリットはかなりある，ただし，作業負担はゼロ ではないため，ボランティア等では厳しく，中核と なる組織が必要である。一方，既存の組織の場合， 各行政の所掌や個別企業の利益最大化とは合致しな い可能性もあり作業が難しい場合も多く，この目的 に専従できる中立性があった方がよいと思われる.

\section{（2）地方自治体・国等が保有するデータの類型化}

前節での役割分担をふまえ，貸与依頼を行う地方自治 体・国等が保有するデータが具体的にどのようなタイプ に分けられるかについて，実際に行う依頼・収集・加工 等，各プロセスでどの程度の手間が生じるかを分析する ことにより, 類型化した結果が表-3である.

大きく分けると，タイプ1は生データそのものを公開 しているが，タイプ1以外は公開していない。また，生 データを公開していない中でもタイプ2〜4は，閲覧用の データを何らか公開しており，その主体が国・都道府 県・市町村などによって収集のしや寸さも変わってくる ため，分けている．さらにタイプ5〜7はデータを閲覧す ることもできないが，データの所在情報だけが公開され ているため，何らかの申請，貸与依頼，購入等を行えば 入手できる可能性が高い.

表-3 地方自治体・国等が保有するデータの依頼・収集・加工等のプロセスにおける類型化

\begin{tabular}{|c|c|c|c|c|c|c|c|c|}
\hline \multirow[b]{2}{*}{$\frac{\text { 区 }}{\text { 分 }}$} & \multirow[b]{2}{*}{ タイプ } & \multirow[b]{2}{*}{ データ例 } & \multicolumn{5}{|c|}{ 各プロセスにおける手間 } & \multirow[b]{2}{*}{ 総合的な負担と実現性 } \\
\hline & & & 依頼 & 収集 & $\begin{array}{l}\text { 実データ } \\
\text { 整形 }\end{array}$ & $\begin{array}{l}\text { メタデー } \\
\text { タ作成 }\end{array}$ & 登録 & \\
\hline 1 & $\begin{array}{l}\text { Web 公開情報であり生データの } \\
\text { 入手も容易だが，多少の整形す } \\
\text { る必要のあるもの }\end{array}$ & 国土数值情報 & $\begin{array}{l}\text { 原則, 不要 } \\
\text { (二次利用の) } \\
\text { 旨) }\end{array}$ & 不要 & 分解 & 必要 & 必要 & $\begin{array}{l}\text { 承認を得られれば使い } \\
\text { やすい }\end{array}$ \\
\hline 2 & $\begin{array}{l}\text { Web 公開情報だが，閲覧用のた } \\
\text { め，保有者から生データを借り } \\
\text { て整形する必要のあるもの }\end{array}$ & $\begin{array}{l}\text { 道路基蕉点情報，ボ } \\
\text { ーリング情報等 }\end{array}$ & \begin{tabular}{|l|} 
必要 \\
(コンテンツ提 \\
供の承認必要)
\end{tabular} & 不要 & 分解 & 必要 & 必要 & $\begin{array}{l}\text { 承認を得られれば使い } \\
\text { やすい }\end{array}$ \\
\hline 3 & $\begin{array}{l}\text { Web 公開情報だが，主体数が多 } \\
\text { いため，自ら収集した方が効率 } \\
\text { 的なもの（ただし，とくに整形 } \\
\text { の必要はないもの) }\end{array}$ & $\begin{array}{l}\text { ハザードマップ, 観 } \\
\text { 光ガイドマップ等 }\end{array}$ & $\begin{array}{l}\text { 不要 } \\
\text { (公開済み) }\end{array}$ & 必要 & 不要 & 必要 & 必要 & $\begin{array}{l}\text { 自ら収集できるので自 } \\
\text { 律性は高い }\end{array}$ \\
\hline 4 & $\begin{array}{l}\text { Web 公開情報だが，主体数が多 } \\
\text { いため，自ら収集・整形した方 } \\
\text { が効率的なもの }\end{array}$ & $\begin{array}{l}\text { 入札公告, 発注見通 } \\
\text { 乙等 }\end{array}$ & $\begin{array}{l}\text { 不要 } \\
\text { (公開済み) }\end{array}$ & 必要 & 必要 & 必要 & 必要 & $\begin{array}{l}\text { 自律性が高いが, 内容 } \\
\text { がばらばらなので整理 } \\
\text { が大変 }\end{array}$ \\
\hline 5 & $\begin{array}{l}\text { Web 上でデータ存在の記載のみ } \\
\text { があり，申請承認の上で，人手 } \\
\text { できるもの }\end{array}$ & $\begin{array}{l}\text { 道路基盤地図情報, } \\
\text { 森林計画図 }\end{array}$ & $\begin{array}{l}\text { 必要 } \\
\text { (申請ベース) }\end{array}$ & 不要 & 原則不要 & 必要 & 必要 & $\begin{array}{l}\text { 承認を得られれば使い } \\
\text { やすい }\end{array}$ \\
\hline 6 & $\begin{array}{l}\text { 空口閲覧等はできるものの，Web } \\
\text { 未公開なため貸与依頼が必要な } \\
\text { もの }\end{array}$ & $\begin{array}{l}\text { 道路工事図面，電子 } \\
\text { 納品成果等 }\end{array}$ & $\begin{array}{l}\text { 必要 } \\
\text { (コンテンツ提 } \\
\text { 供の承認必要) }\end{array}$ & 不要 & 必要 & $\begin{array}{ll}(※) & \text { 要 } \\
(※)\end{array}$ & 必要 & $\begin{array}{l}\text { データが電子化されて } \\
\text { いない, あるいは個別 } \\
\text { のまま整理されていな } \\
\text { い可能性もある }\end{array}$ \\
\hline 7 & $\begin{array}{l}\text { 関係機関のみで共有しているも } \\
\text { の }\end{array}$ & $\begin{array}{l}\text { 道路管理データ, 一 } \\
\text { 部ボーリングデータ }\end{array}$ & $\begin{array}{l}\text { 必要（ただし有 } \\
\text { 償になるケース } \\
\text { あり） } \\
\end{array}$ & 不要 & 原則不要 & $\begin{array}{l}\text { ケースバ } \\
\text { イケース }\end{array}$ & 必要 & $\begin{array}{l}\text { 対価を払えれば問題な } \\
\text { い. 独自形式の場合も } \\
\text { ある }\end{array}$ \\
\hline 8 & $\begin{array}{l}\text { データが存在することもよくわ } \\
\text { からないもの }\end{array}$ & 航空写真等 & 必要 & 不要 & ケースバ & 必要 & 必要 & $\begin{array}{l}\text { 担当によって対応が変 } \\
\text { わる可能性 }\end{array}$ \\
\hline 9 & RSSによるニュース等 & 事故や気象データ等 & 不要 & 不要 & 原則不要 & 不要 & 必要 & $\begin{array}{l}\text { データ保有機関側の負 } \\
\text { 担になる可能性. また } \\
\text { ニュースレベルのテキ } \\
\text { ストデータが多い }\end{array}$ \\
\hline 10 & リンクによるニュース等 & 色々 & 不要 & 不要 & 不要 & 不要 & 不要 & 情報量は多くない \\
\hline
\end{tabular}

(※1) メタデータが何もない場合には1件ずつ手入力が必要. 電子納品成果の場合はメタデータが利用可能. 
また，タイプ8は「データがあるようだ」といった推 測レベルでデータの所在が知られているものもある. 逆 にタイプ9, 10はニュースレベルなので，情報量は多くな いが，保有者側が積極的にデータ利用を推進しているも のである.

タイプ1のケースは生データをもともと公開している ため二次利用がしや寸いが，タイプ2〜40場合は生デー タを公開していないため, 二次利用をしやすくするため には，依頼により生データを入手する必要がある. とく にタイプ3や4はタイプ2に比べ，データ保有者が個々の 地方自治体となるので，依頼や収集が個別に必要となり， かなりの労力がかかる，場合によっては，生データの収 集はあきらめ, 加工ができないものの何らかのデータを Web上でプログラムによる自動収集（クローリング）等 を行った方が効率的なケースもある.ただし，タイプ3 のハザードマップや観光ガイドマップ等それぞれのPDF 等がそのままの形で価值を持つものは加工を要しないの で整形負担はない. 一方, タイプ4の工事の入札公告や 発注見通しのように，表形式などで公開されているもの の形式は個別ばらばらなので，集約のために整形しない と価值が出ないものは一定のシステム化が必要である.

さらに，タイプ5〜7は，データが存在することしかわ からないものの，Webを通じて入手できる可能性がある もの（タイプ5），空口閲覧を通じてのもの（タイプ6）， 会費等を払い参加することにより可能になるもの（タイ プ7）などで入手のしやすさに差が出る.これらはもと もと電子データで整備されていることも多く, 必要性が 認められれば生データが利用できるケースも多い.ただ し，紙でしか存在しない場合は，利用にあたって一定の コストが生じる。またタイプ8は，あるかどうかをデー 夕保有者に確認するところから始まるため, かなりの手 間がかかってしまう。

\section{(3) プラットフォームの機能要件}

次に，前節で述べたデータを登録し，検索・利用する ためのプラットフォームの機能要件について整理する. 本研究では様々な性格のデータが流通できることを目的 としているため, データ検索や登録を中心に機能はシン プルであるが，こうした機能が実用上支障がなく動くこ とを必要条件とした。

表-4はシステムの機能要件として最低限必要な機能を 整理したものだが，データのカテゴリー（種類）と地域 （行政区分）のクロス検索ができ，その結果をダウンロ 一ドできることが最も重要な点である，それ以外に，結 果を地図表示できること，その表示範囲のみで検索でき ること，あるいはフリーワード入力によるメタデータの 検索なども実用的には重要である.

一方データ登録では実データのファイルをメタデータ とともに効率的に登録できることが重要である，大別す ると，ファイルを一つずつメタデータとともに入力する ケースと, 複数地点の複数ファイルを予め作成したメタ データとともにまとめて登録するケースがあり，両機能 を実装した．また修正機能や，一括ダウンロードを実現 するために複数ファイルを圧縮する機能等も必要である.

また，これらの機能要件に合わせ，本研究で設定した メタデータは表-5のとおりである。詳細は薄井ら (2010）与去照されたい.

\begin{tabular}{l|l}
\multicolumn{2}{|c}{ 表-4 メタデータ定義 } \\
\hline 項目 & 内容 \\
\hline ID番号 & データの固有 $\mathrm{D}$ \\
\hline タイトル & データタイトル (例) OO保育園 \\
\hline カテゴリ & 分類情報 (例) 公共施設 (保育園) \\
\hline 内容 & データの詳細情報 \\
\hline リンク情報 & 対象施設に関するURL情報 \\
\hline 位置情報 & 対象データの所在地の経緯度 \\
\hline 著作権 & データの著作権 \\
\hline 作成者 & データ作成者 \\
\hline 作成日付 & データダ作成された日付 \\
\hline 登録日付 & データをシステムに登録した日付 \\
\hline
\end{tabular}

表-5 システムの機能要件（薄井ら（2010）のをもとに作成したもの）

\begin{tabular}{|c|c|c|c|}
\hline 機能 & 機能詳細 & 利用対象 & 内容 \\
\hline \multirow[t]{5}{*}{ 検索機能 } & キーワード検索機能 & 利用者 & フリーワード入力によるメタデータの検索ができる（最大 2 単語の AND検索に対応） \\
\hline & 行政区分別検索機能 & 利用者 & 都道府県・市区町村の行政区分別で検索ができる（プルダウン） \\
\hline & カテゴリ検索機能 & 利用者 & カテゴリ区分別のメタデータの検索ができる（プルダウン） \\
\hline & 地図表示範囲検索機能 & 利用者 & 画面表示されている地図域内におけるメタデータの検索ができる \\
\hline & ダウンロード機能 & 利用者 & $\begin{array}{l}\text { メタデータ検索結果から必要なデータを選択し, 実データ (Original データ) を圧縮して } \\
\text { ダウンロードできる }\end{array}$ \\
\hline \multirow[t]{4}{*}{ 登録機能 } & 登録機能（個別） & 提供者 & 本システムに Web上でメタデータと実データを個別登録できる \\
\hline & 登録機能 (一括) & 提供者 & 複数のメタデータと実データを一括して登録できる \\
\hline & 修正機能 & 提供者 & $\begin{array}{l}\text { 既登録済みのデータに対し，位置情報を含むデータの属性情報及び実データを修正・再 } \\
\text { 登録できる }\end{array}$ \\
\hline & 圧縮機能 & 利用者 & 様々な実データの一括ダウンロード実現のために複数ファイルを圧縮できる \\
\hline \multirow[t]{2}{*}{ ユーザ管理 } & ログイン機能 & 利用者 & 実データダウンロードに必要なログインできる \\
\hline & 管理機能 & 管理者 & 登録されたユーザの属性情報の修正，削除ができる \\
\hline
\end{tabular}




\section{4. 実証実験}

\section{(1) コンソーシアムの構成と利用規約}

前章までの制度設計を実証するために実験を行った。 具体的には利用規約や次節で述べるデータ構成をWeb上 で公開した上で，参加者を2回（2009年11～12月と2010年 7～8月），それぞれ約1ヶ月間公募したところ，合わせ て125法人から申し込みがあった。 なお，具体的な利用 規約は，以下に箇条書きを行った事柄などを含んでおり， 提供者側のリスクが過大にならないよう配慮しており， 参加者側にも利用規約を遵守寸る旨の誓約書を出して頂 いた上で参加頂いた．参加者の内訳は図-3のとおりであ り，民間企業が多くなっている.

・ 利用用途の制限はとくにかけないもののデータの出

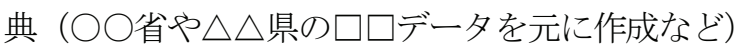
を明記すること

- 利用目的や方法については，コンソーシアムや提供 元は一切責任を持たないこと

- 実験期間終了後使用し続ける場合は提供元に許可を 取る必要があること

\section{(2) データ構成}

本研究では，国土や公共施設に関する情報を対象とし ており，ボーリング柱状図，各種公共施設，道路工事関 連情報，道路基準点，森林基本図，各種政策情報等，幅 広いデータを収集し, 結果として約40種類, 約40万地点 の情報となった. これらを分類し，データ種類，データ タイプ，コンソーシアムでの提供範囲，提供形式，デー 夕数の軸で整理したものが表-6である.

これらデータの整備や提供の状況は当然, データの性 質により多様であるが，大きく分ければ，国がまとめて 整備・提供を行っているものと，都道府県レベルのもの， 市町村レベルのものがあり，道路のように管理者がいく つか存在するものは，それぞれで整備されている．基本 的に各データごとに整備主体に貸与依頼を出すことにな

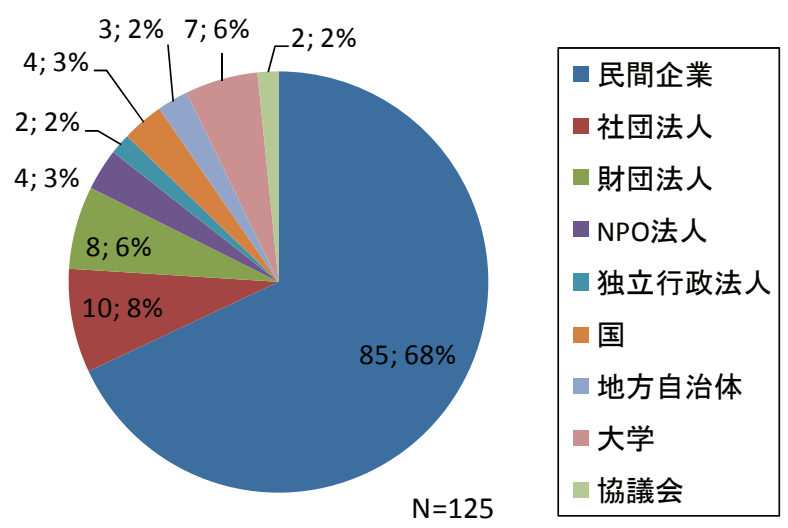

図-3 コンソーシアム参加者の内訳
るため，国であれば，該当する部課室が提供の可否を判 断することになるが，都道府県であれば47都道府県それ ぞれに依頼を出すため，各都道府県による判断となる. 具体的には，ボーリング柱状図・道路工事困面・森林基 本図／森林計画図などは各都道府県で整備しており，そ の提供依頼に対する判断は分かれ，実際に提供があった のは，ボーリングで8県，森林情報で5県，道路工事図面 で25都道府県であった。これを詳細に表現したものが図 -4であり，傾向はデータの種類によって様々であるもの の，半数近くの都道府県から回答がない点は共通である. また，ボーリングでは，16の道県が提供の意向を示した ものの途中でメールの返信等がなく，提供に至らなかっ たものも半数程度あった（こちらからの確認メイルは1 回程度に抑えている）。一方，道路については，国の 「デジタル道路地図更新業務」の一環として各都道府県 が年に1回程度集約して提出しており，その成果を使っ て欲しいという要請があり，実際の手続きも都道府県の 手を煩わせるのではなく国の出先機関から直接借り受け る，という負担の少ないやり方を採用したことがよかっ たようである。

また，データのタイプを表-3の区分に従って分類した が，元々公開されている生データ（タイプ1）は国土交 通省国土計画局の国土数值情報等しかなく，あとは何ら かの形で依頼を行ったり，全国的にクローリングを行っ て収集したものが多い.たとえばタイプ2である「道路 基準点」は，元々は提供元の国土技術政策総合研究所の サイトから閲覧することができていたが，生データを貸 与頂くことができたため，メタデータを作成し登録を行 った。また，タイプ4とした「道路供用開始の公示情 報」「工事入札／道路開通情報」「工事発注見通し情 報」は市町村単位での情報提供であるため，それぞれの 市町村からの生データの収集はあきらめて，クローリン グ等により，収集・整形を行った。 あるいは，タイプ7 とした「道路管理データ」は，データの所在は道路管理 センター (http://www.roadic.or.jp) に記載されているが, 実際に会費を払っている会員企業・自治体が使えるデー タである，そのため本研究では，一般利用者の意見をも らうために，一部の地域のデータのみ貸与頂いた.

これらデータの提供形式は，元々がテキスト中心の情 報はCSV等が中心となり，図面が中心のものはPDFや XML, CAD等が中心となった。

\section{(3) システム構成}

一方で，システムは，3.(3)のプラットフォームの機能 要件を満足するように図-5の構成で構築した。詳細は薄 井らのを参照されたいが，サーバは，WindowsServer2008 の2 機構成とし，それぞれWeb サーバ，Database（DB） サーバとしての機能を持たせた. Webサーバは, Apache 


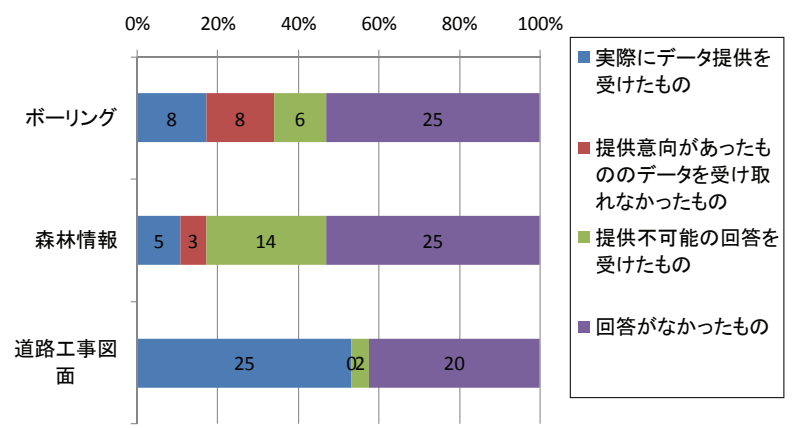

図-4 都道府県の提供状況（ボーリング，森林情報，道路工事 図面)

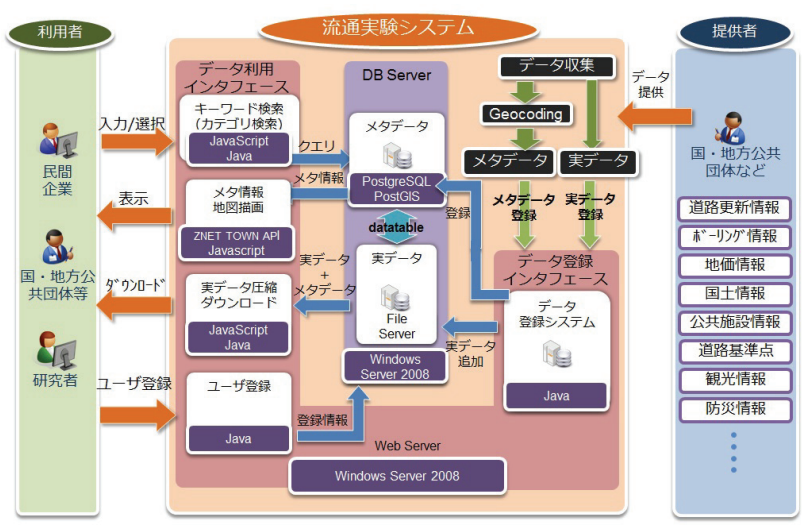

図-5 システム構成

表-6 データ構成（2011年3月時点）

\begin{tabular}{|c|c|c|c|c|c|}
\hline 分類 & データ種類 & $\begin{array}{l}\text { タイプ（表-3 } \\
\text { の区分） }\end{array}$ & 提供範囲（提供元） （※1） & 提供形式 & $\begin{array}{l}\text { データ } \\
\text { 数 }\end{array}$ \\
\hline 地盤情報 & ボーリング柱状図 & $\begin{array}{l}\text { 国は 2, 都道府 } \\
\text { 県は 2,7,8 } \\
\end{array}$ & $\begin{array}{l}\text { 国管轄の全範囲（国土交通省・土 } \\
\text { 木研究所）と } 7 \text { 県 }(※ 2)\end{array}$ & XML, XLS, PDF & 86,148 \\
\hline 地価情報 & 地価公示／地価調査 & 1 & \multirow{3}{*}{ 全国（国土交通省国土計画局） } & CSV & 51,251 \\
\hline 国土インフラ情報 & ダム／漁港／空港他 & 1 & & CSV & 7,485 \\
\hline 公共施設情報 & 各種公共施設 & 1 & & CSV & 195,961 \\
\hline \multirow{4}{*}{ 道路更新情報 } & $\begin{array}{l}\text { 道路供用開始の公示情報（道路法第 } \\
18 \text { 条） }\end{array}$ & 4 & 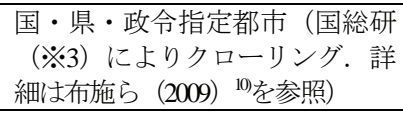 & CSV & 1,622 \\
\hline & 工事入札公告／道路開通情報 & 4 & $\begin{array}{l}\text { 三重県・岐阜県・大阪府（東大 } \\
\text { CSISによりクローリング） }\end{array}$ & TXT,PDF 等 & $\begin{array}{l}4,713 \\
312 \\
\end{array}$ \\
\hline & 工事発注見通し情報 & 4 & $\begin{array}{l}\text { 全国の地方自治体 (※4) } \quad \text { （東大 } \\
\text { CSISによりクローリング. 詳細は } \\
\text { 関本ら (2012) }{ }^{11)} \text { を参照) } \\
\end{array}$ & TXT & 26,932 \\
\hline & 道路工事図面 & 6 & $\begin{array}{l}\text { 国直轄の全範囲と } 25 \text { 都道府県 } \\
\text { (2009年度分) }\end{array}$ & \begin{tabular}{|l} 
CSV, CAD, PDF, \\
XML 等
\end{tabular} & 1,838 \\
\hline \multirow{3}{*}{ 道路関係情報 } & 道路基淮点情報 & 2 & 国直轄のほぼ全域（国総研） & CSV & 17,826 \\
\hline & 道路管理データ & 7 & $\begin{array}{l}\text { 横浜市全域（財団法人道路管理セ } \\
\text { ンター) }\end{array}$ & SHP & 28 \\
\hline & 道路基盤地図情報 & 5 & 国直轄の一部（国総研） & XML, SXF & 44 \\
\hline \multirow{2}{*}{ 森林情報 } & 森林基本図 /森林計画図 & $5,6,8$ & 6 県 (※5) & SHP & 26 \\
\hline & 路網 & 6,8 & 岐阜県・鳥取県・福岡県 & SHP,PDF, XLS & 25 \\
\hline 観光情報 & 観光施設 & 2 & 三重県 & メ夕情報のみ & 296 \\
\hline \multirow{4}{*}{$\begin{array}{l}\text { 自然環境への取組情 } \\
\text { 報 }\end{array}$} & $\begin{array}{l}\text { いきいき下水道・生る水 } 100 \text { 選/水 } \\
\text { の鄉百選 }\end{array}$ & 10 & $\begin{array}{l}\text { 全国（国土交通省都市・地域整備 } \\
\text { 局） }\end{array}$ & HTML & 188 \\
\hline & エコエアポート & 10 & 全国（国土交通省航空局） & HTML & 25 \\
\hline & リサイクルポート & 10 & 全国（国土交通省港湾局） & HTML & 21 \\
\hline & アユの遡上マップ & 10 & \multirow[b]{2}{*}{ 全国（国土交通省河川局） } & HTML & 88 \\
\hline \multirow[t]{2}{*}{$\begin{array}{l}\text { 安心・安全・防災の } \\
\text { 取組情報 }\end{array}$} & $\begin{array}{l}\text { ダムの諸量／河川整備基本方針・河 } \\
\text { 川整備計画／浸水想定区域図・洪水 } \\
\text { ハザードマップ } \\
\end{array}$ & 10 & & HTML & 593 \\
\hline & 験潮場 & 10 & 全国（国土地理院） & HTML & 25 \\
\hline $\begin{array}{l}\text { 多様性のある地域形 } \\
\text { 成の取組 }\end{array}$ & 鉄道を元気にする34の取り組み & 10 & 全国（国土交通省鉄道局） & HTML & 34 \\
\hline
\end{tabular}

$(※ 1)$ 提供元は 2011年3月時点の組織名 $\quad(※ 2)$ 岩手・群馬・滋賀・鳥取・岡山・徳島・鹿児島 $\quad(※ 3)$ 国土技術政策総合研究所

(※4）ただし公開している23程度の自治体が対象（※5）埼玉・長野・岐阜・鳥取・山口・福岡

とTomcat を用いてJava ベースのシステムを構築し，DB へのアクセスはJDBCにより行っている.

本システムの特徵は，PostgreSQL にPostGIS を組み込み， 地理空間情報に関するデータ格納に適したデータベース へと拡張している点にある. 既存のPostgreSQL データベ ースでは，位置情報やポリゴン情報などデータ形式が違 うデータに対し，それぞれDB フィールド（カラム）を
作成し格納しなければならない。しかし，PostGISを使 うことによって，それら空間情報をGIS オブジェクトと して扱うことができ，1つのDB フィールドを用意する だけで様々な空間情報を格納できるようになる。また，

R-Tree の空間インデックスもあるため空間検索の効率が 上がることも特徵である．本システムではこの機能を活 用することにより，より高速で効率の良い検索システム 
を構築している.

また，検索結果を地図上にプロットし利用者に直感的 にデータの所在を示すために, ゼンリン住宅地困ネット 配信サービス『ZNET TOWN』のAPI を利用し地図操作 を可能にしている.

ユーザー側が直接利用する検索等の画面は図-6のよう になっている. すなわち, コンソーシアムの会員はIDに よりログインすることができ，地域（市町村レベルま で）とデータカテゴリーを選択することにより，登録さ れているデータの検索結果が画面左端のように表示され るとともに，地図上にも分布状況が表示される．それら の点のどれかをクリックすると属性が表示される. 検索 結果の上部にあるダウンロードボタンを押すと, 別途ダ ウンロード画面に遷移し，データのダウンロードできる. また，このサイトは公開されており，勋なくても検索 結果を閲覧することまでは可能になっている.

\section{(4) 利用状況}

システムの利用状況についてまとめたものが表-7であ る. システムを運用していた2009年12月～2011年2月ま での1年強の間に，125法人のほとんど全ての団体が利用 し，検索以外に実データをダウンロードしたユーザーは 68人にのぼった。 また，1日あたり，平均検索回数が 27.5 回で，平準化された利用があったと見られ，ログインユ 一ザー 1 人あたりの平均ログイン回数も 6.1回と多く, ある程度の繰返し利用があったと思われる。

また, カテゴリ一別の利用状況をまとめたものが表-8 である．純粋なダウンロード地点数は，ボーリング柱状 図や道路基準点が多いが，各カテゴリの利用人数を実デ 一タダウンロードユーザ数の合計68人で割り，ユニーク ユーザの割合を見る利用率にしてみると，ボーリング柱 状図や道路工事図面などの利用が多いことがわかる.

なお，これらについて上記実験期間中の具体的な検索 状況を日付とともにグラフ化したものが図-7である. 概 ねデータ登録や記者発表等があった時に検索回数が増え る傾向はあるがそれ以外の日にも一定の利用が見られる.

\section{(5) 利用者アンケート結果}

前節のような客観的な值に加え，コンソーシアムでの サービス開始当初（2010年2月）と終了直前（2011年2 月）の2回にわたり，会員への直接のアンケートも行っ た. 図-8は，今回のようなプラットフォームが今後, 持 続的なサービス提供を行えるかどうかを検討するために， 支払い意思を聞いたものである. 終了直前時には協議会 に移行し有料化の可能性もあるとアナウンスしていたた め, 開始当初より「有償でも利用する」という回答が若 干減っているが，「条件による」を含めると，約9割が 何らかの形で利用する可能性があることを示している.
ただし，「有償」の意味は個別データについての料金支 払いを示しているのではなく, データ収集・加工作業に 係る実費相当額を支払う意味である.

また，これらの支払い意思額に応じてプラットフォー ムが提供すべき項目を聞いた結果が図-9であり，これか ら以下が読み取れる.

・支払い金額が高くなるほど，選択される利用条件が 多くなる傾向にある.

・支払い金額の上昇とともに，選択される率が高くな る条件は「分野的な網羅性（条件3）」「検索性 (条件5）」「利用可能頻度（条件6）」である. 逆 に支払い金額によらず多く挙がったのは「更新性

(条件1）」「地域的な網羅性（条件2）」「信頼性 (条件4)」であつた.

つまり，データそのものに対する要望は，金額の多寡 に関わらず必須と考える人が多い一方, データの検索 性や利用可能頻度は，システムの機能やサービスに関 わる項目であり，支払い金額が高くなる場合は，シス テムの機能に対する要望も高くなることがうかがえる.

さらに，こうした公共のデータとともに，一部民間側 のプロダクトとして販売されているデータを流通プラッ トフォームによって提供する可能性について尋ねたとこ ろ，図-10のように，2/3程度が何らかの利用可能性があ ることを示している.

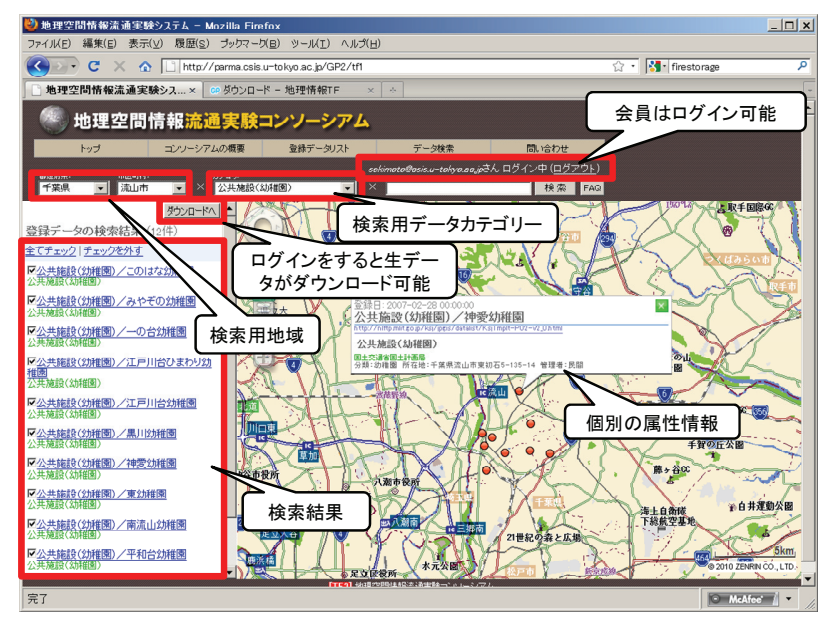

図-6 システム画面

表-7 システムの基礎的な利用状況

\begin{tabular}{l|l}
\hline 集計項目 & 集計值 \\
\hline 参加団体 & 123 団体 \\
\hline 参加人数 (ユーザ登録者数) & 182 人 \\
\hline システム利用日数 & 310 日 \\
\hline データ総検索回数 & 8512 回 \\
\hline 1日あたりの平均検索回数 & 27.5 回 $/$ 日 \\
\hline 全期間のログインユーザ数 & 154 人 \\
\hline ログインユーザ一人あたりの平均ログイン回数 & 6.1 回 $/ 人$ \\
\hline 実データのダウンロードユーザ数 & 68 人 \\
\hline 実データのダウンロードデータ総数 & 112,774 個 \\
\hline
\end{tabular}




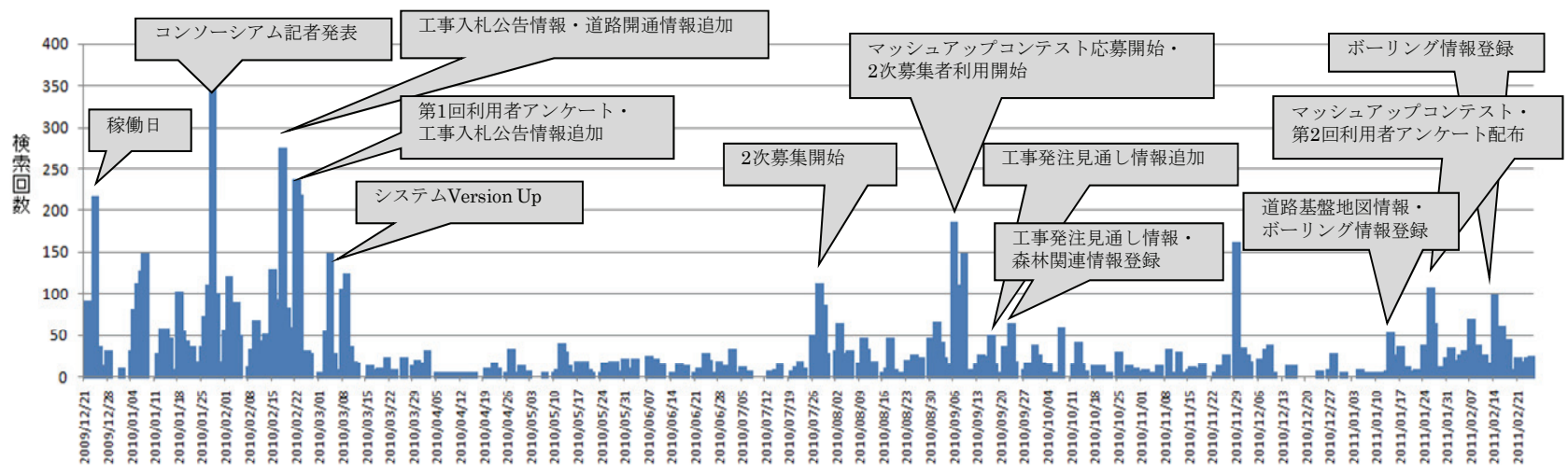

図-7 システム利用状況

表-8 カテゴリー別の利用状況（上位10件のみ）

\begin{tabular}{l|l|l|l|l}
\hline \multirow{2}{*}{ 順位 } & カテゴリ名 & $\begin{array}{l}\text { ダウンロ } \\
\text { ード数 }\end{array}$ & $\begin{array}{l}\text { 利 用 } \\
\text { 数 }\end{array}$ & $\begin{array}{l}\text { 利 } \\
\text { 率 }\end{array}$ \\
\hline 1 & ボーリング柱状図 & 33,096 & 25 & $37 \%$ \\
\hline 2 & 道路工事図面情報 & 4,506 & 23 & $34 \%$ \\
\hline 3 & 公共施設 (小学校) & 1,935 & 15 & $22 \%$ \\
\hline 4 & 道路開通情報 & 49 & 14 & $21 \%$ \\
\hline 5 & 公共施設 (その他) & 974 & 13 & $19 \%$ \\
\hline 6 & H20 地価公示 & 2,872 & 13 & $19 \%$ \\
\hline 7 & H20都道府県地価調査 & 967 & 12 & $18 \%$ \\
\hline 8 & 公共施設 (国の機関) & 2,659 & 11 & $16 \%$ \\
\hline 9 & 道路基準点情報 & 40,898 & 11 & $16 \%$ \\
\hline 10 & 公共施設 (中学校) & 1,035 & 10 & $15 \%$ \\
\hline
\end{tabular}

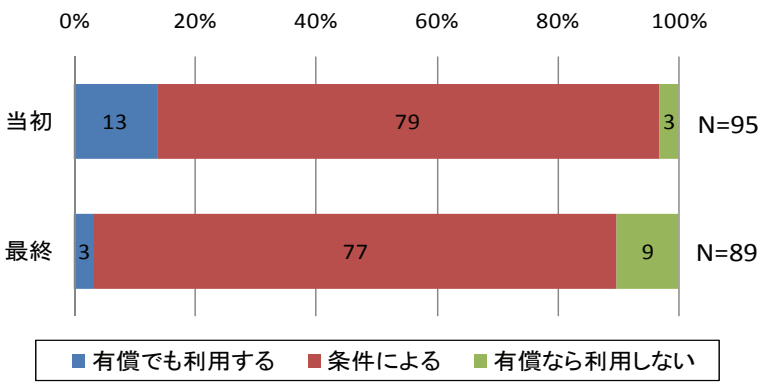

図-8 有償でのサービス利用意向（サービス開始当初と終了時 の比較)

$\begin{array}{lllllllllll}0 & 10 & 20 & 30 & 40 & 50 & 60 & 70 & 80 & 90 & 100 \\ \%\end{array}$

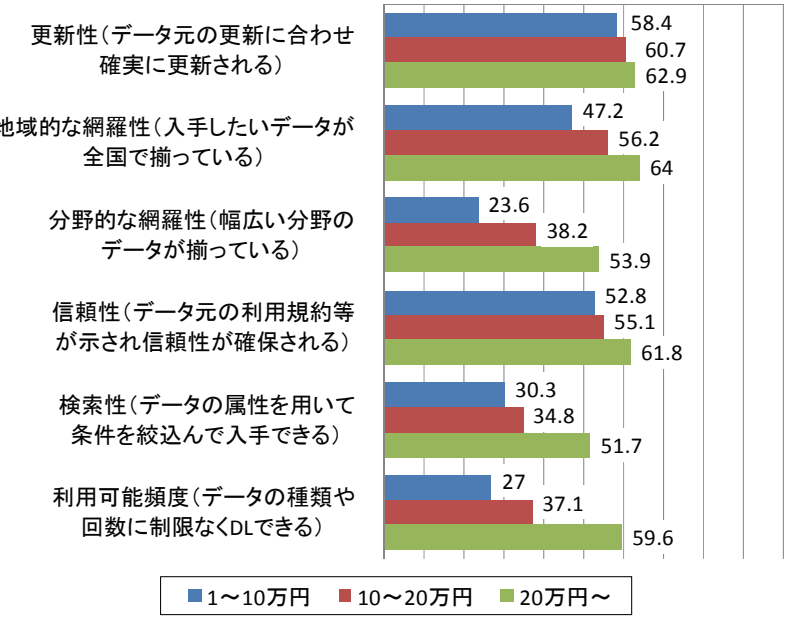

図-9 支払い意思額に応じてシステムが明示すべき要件

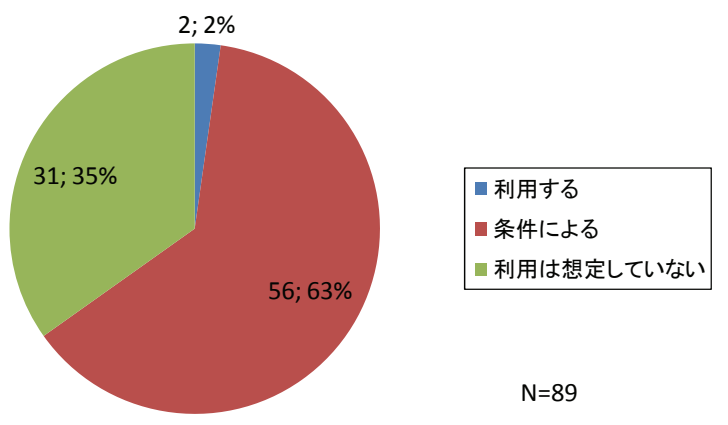

図-10 民間データ販売ルートとしてのプラットフォームの利用 意向

\section{(6) 提供者アンケート結果}

一方で，今回，貸与依頼を行った全ての自治体から貸 与頂いたという訳ではなかった。 今後データ提供を受け るためにも，データ提供者側のハードルとなる事項も把 握する必要があり，いくつかの質問を行ったアンケート 結果が表-9〜12である. なお，県に対しては，何らかの データを提供して頂いた16団体に送付し，9団体の回答 を得ることができ，市町村には71団体に送付し，12団体 から回答が得られた。

まず，今回，データ提供者側からデータを提供して頂 いたのは，トレーサビリティのある，利用者が限定され たコミュニティに対してである。こうした利用者限定の 制約が今後も必要かどうか確認したところ，表-9のよう に過半数の自治体は今回のように利用者を限定する以外 の条件では提供したくないことがわかった。

次に，提供元に許諾を求めるタイミングについて聞い た. 今回は事前にコンソーシアムの趣旨を説明し，誰か が利用するたびに提供元に許諾を求める，という手間の かかることを行わなかったが，この許諾のタイミングに ついて聞いたところ，表-10のように，今後も利用のつ ど事前許諾は必要としないが，事後に，例えば年度末な どにまとめて利用状況を知りたい，という意見が多かっ た. 提供者側の許諾の手間が増えるのは避けつつも利用 
表-9 利用者限定の必要性について

\begin{tabular}{|c|c|c|c|c|}
\hline & \multicolumn{2}{|l|}{ 県 } & \multicolumn{2}{|c|}{ 市町村 } \\
\hline & $\begin{array}{l}\text { 回 答 } \\
\text { 数 }\end{array}$ & 割合 & $\begin{array}{l}\text { 回 答 } \\
\text { 数 }\end{array}$ & 割合 \\
\hline $\begin{array}{l}\text { 1. 今後もメンバーの事前登録を継 } \\
\text { 続し, ダウンロード可能な利用 } \\
\text { 者を限定した方がよい }\end{array}$ & 5 & $56 \%$ & 6 & $50 \%$ \\
\hline $\begin{array}{l}\text { 2. 今後はメンバーの事前登録を行 } \\
\text { わず，情報提供の利用者を限定 } \\
\text { しない方向がよい }\end{array}$ & 2 & $22 \%$ & 0 & $0 \%$ \\
\hline 3.わからない & 2 & $22 \%$ & 6 & $50 \%$ \\
\hline
\end{tabular}

表-10 利用者への許諾タイミングについて

\begin{tabular}{|c|c|c|c|c|}
\hline & \multicolumn{2}{|l|}{ 県 } & \multicolumn{2}{|c|}{ 市町村 } \\
\hline & $\begin{array}{l}\text { 回 } \\
\text { 答 } \\
\text { 数 }\end{array}$ & 割合 & $\begin{array}{l}\text { 回 } \\
\text { 答 } \\
\text { 数 }\end{array}$ & 割合 \\
\hline $\begin{array}{l}\text { 1. 今後はダウンロード前に利用者を確 } \\
\text { 認する必要がある (都度, ダウンロ } \\
\text { ードの可否を判断したい) }\end{array}$ & 1 & $11 \%$ & 2 & $17 \%$ \\
\hline $\begin{array}{l}\text { 2. 今後もダウンロード後でもよいの } \\
\text { で, 利用者を確認する必要がある }\end{array}$ & 5 & $56 \%$ & 6 & $50 \%$ \\
\hline 3.今後は利用者を確認する必要はない & 2 & $22 \%$ & 0 & $0 \%$ \\
\hline 4.わからない & 1 & $11 \%$ & 4 & $33 \%$ \\
\hline
\end{tabular}

状況を把握するために，年1回程度まとまった形で報告 を受けることが望まれていることがわかり，これは利用 者や管理者にとっても負担が減ることである.

さらに提供者側のデータ管理主体の組織レベルについ て尋ねた結果が表-11である。これは都道府県と市町村 で違いがかなり鮮明であり, 都道府県では部単位での管 理が最も多く, 上位の組織的対応が多いことに比べて, 市町村では，担当者あるいは係レベルの管理が多く，個 人的対応に委礼られていることがわかる.

最後に，提供者自身に提供へのハードルとなっている 事項を聞いたところ，表-12のような結果となった。 こ の表によると, 比較的多数の県と市町村で「提供後にデ 一タがどのように利用されるかわからない」「データが デジタルではない」「データが一元的に管理されていな いため収集が困難」「これまで外部に提供した実績がな い」が共通的な障害として挙げられている. 市町村単独 で挙げられている要因として，「自治体が整備したデー 夕なので，自治体外部の住民一の公開ができない」とい う回答がある. 一方，「提供に対して障害はない」とい う回答も1県から寄せられている.さらに, 公共測量の 成果については, 測量法に規定されている使用承認・複 製の手続きが必要になるという指摘もあった.

これらのことから，データの提供にあたっては，

「デジタル化」といった作業的な対応に加えて, 外部提 供のための仕組みの構築，測量法の規定との整合性の確 保といった検討が必要なことがわかった。
表-11 データ管理の主体

\begin{tabular}{l|l|l|l|l}
\hline \multirow{2}{*}{} & \multicolumn{3}{|l|}{ 県 } & \multicolumn{2}{l}{ 市町村 } \\
\cline { 2 - 5 } & $\begin{array}{l}\text { 回 答 } \\
\text { 数 }\end{array}$ & 割合 & $\begin{array}{l}\text { 回 答 } \\
\text { 数 }\end{array}$ & 割合 \\
\hline 1.担当者単位 & 0 & $0 \%$ & 4 & $33 \%$ \\
\hline 2. 係単位 & 0 & $0 \%$ & 2 & $17 \%$ \\
\hline 3.課単位 & 2 & $22 \%$ & 4 & $33 \%$ \\
\hline 4.部単位 & 4 & $44 \%$ & 0 & $0 \%$ \\
\hline 5. 局単位 & 0 & $0 \%$ & 0 & $0 \%$ \\
\hline 6. 事務所単位 & 1 & $11 \%$ & 0 & $0 \%$ \\
\hline 7.団体全体で一元的に管理 & 1 & $11 \%$ & 0 & $0 \%$ \\
\hline 8.その他（選択肢なし） & 1 & $11 \%$ & 2 & $17 \%$ \\
\hline
\end{tabular}

表-12 提供へのハードルとなる事項

\begin{tabular}{|c|c|c|c|c|}
\hline & \multicolumn{2}{|l|}{ 県 } & \multicolumn{2}{|c|}{ 市町村 } \\
\hline & $\begin{array}{l}\text { 回 答 } \\
\text { 数 }\end{array}$ & $\begin{array}{l}\text { 割 } \\
\text { 合 }\end{array}$ & $\begin{array}{l}\text { 回答 } \\
\text { 数 }\end{array}$ & $\begin{array}{l}\text { 割 } \\
\text { 合 }\end{array}$ \\
\hline $\begin{array}{l}\text { 1. データがデジタルではない（電子 } \\
\text { 化されていない） }\end{array}$ & 3 & $19 \%$ & 4 & $17 \%$ \\
\hline $\begin{array}{l}\text { 2. データが一元的に管理されていな } \\
\text { いため収集が困難 }\end{array}$ & 3 & $19 \%$ & 6 & $25 \%$ \\
\hline $\begin{array}{l}\text { 3. データ提供について内部の決済が } \\
\text { 得られない.手続きが大変 }\end{array}$ & 1 & $6 \%$ & 0 & $0 \%$ \\
\hline $\begin{array}{l}\text { 4. 自治体が整備したデータなので自 } \\
\text { 治体外部の住民〜公開ができない }\end{array}$ & 0 & $0 \%$ & 3 & $13 \%$ \\
\hline $\begin{array}{l}\text { 5. 提供後にデータがどのように利用 } \\
\text { されるかがわからない }\end{array}$ & 4 & $25 \%$ & 6 & $25 \%$ \\
\hline $\begin{array}{l}\text { 6. これまで外部に提供した実績がな } \\
\text { い }\end{array}$ & 1 & $6 \%$ & 4 & $17 \%$ \\
\hline 7.理由はよくわからない & 0 & $0 \%$ & 0 & $0 \%$ \\
\hline $\begin{array}{l}\text { 8. 提供することに対して障害となる } \\
\text { 事項はない }\end{array}$ & 1 & $6 \%$ & 0 & $0 \%$ \\
\hline 9. その他 & 3 & $19 \%$ & 1 & $4 \%$ \\
\hline
\end{tabular}

(7) マッシュアップコンテスト

さらに, これらの流通データの利活用促進自体も重要 な課題であり, 流通データを利用したアプリケーション がどの程度自然に出てくるかも重要なバロメータである. こうしたデータ利活用の促進活動は他でも最近は,

(独）防災科学技術研究所による「防災マッシュアップ コンテスト」 (http:/bosai-contest.jp/) や, 慶応大学を中心 とした「 Linked Open Data Challenge Japan 」 (http://lod.sfc.keio.ac.jp/challenge2011/) などがあり，本コン ソーシアムでも，「マッシュアップコンテスト」という 形で2010年10月〜2011年1月の間に募集した。 ただし， コンソーシアムのデータは会員に対して公開しているも のなので, 会員内での募集である点は異なっている.

表-13がその結果であるが，9団体から提案があり，利 用したデータは，ボーリング柱状図，森林基本図，道路 工事図面が多く, 実際に生データが公開されていないも のに新規性を見出した提案が多かった．また，各提案に ついては，幹事により，新規性，有用性，信頼性の3点 から公正な評価を行い，上位4者について金賞，銀賞， 銅賞という形で表彰を行った。 


\section{(8) 実験結果の考察}

これら一連の実験で，多くのことが明らかになった。 まず，データの収集という観点では，想定したデータの タイプ（区分）に沿った，多様なデータが存在し，実際 に約40種類，40万地点の情報を収集することができた. また，これらのデータ処理の負担感についても，各タイ プの想定に近いものとなった.

次に，これらのデータ構成や利用規約をWebに示した 上でのコンソーシアムへの参加については, 公募により 125法人の参加があり，コミュニティとしても一定規模 のものが成立することがわかった.

さらにシステムについても，これらの多様かつ大量 のデータを位置情報とともにWeb上に登録し，背景地図 とともに視覚化した．また，「自治体×データの種別」 というシンプルな検索を基本としつつ, 会員向けには生 データのダウンロードを可能にし，各機能をストレスな く利用でき，運用期間中も一定のアクセスが継続的にあ った.

また，これらデータを利活用したアプリケーション提 案がどの程度出るかという意味で行ったマッシュアップ コンテストについても，9団体からの参加があり，とく に，未提供であったデータの利用に対しての提案に新規 性を見出したものが多かった。

最後に，コンソーシアムに参加したデータ利用者に対 するアンケートでは，今後有償であっても条件によって

表-13 マッシュアップコンテスト結果

\begin{tabular}{|c|c|c|}
\hline 表彰 & 団体名 & タイトル \\
\hline 金賞 & 東京電力(森) & $\begin{array}{l}\text { 森林簿利活用による業務品質向上支援 } \\
\text { について }\end{array}$ \\
\hline 銀賞 & オートデスク㑣) & 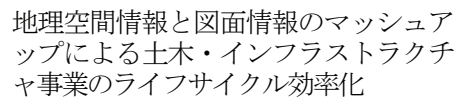 \\
\hline 銅賞 & $\begin{array}{l}\text { (社) 全国地質 } \\
\text { 調査業協会連合 } \\
\text { 会情報化委員会 }\end{array}$ & 地盤災害情報提供サービス \\
\hline \multirow[t]{6}{*}{ 銅賞 } & $\begin{array}{l}\text { パシフィックコ } \\
\text { ンサルタンツ|森) }\end{array}$ & $\begin{array}{l}\text { 森林情報と気象情報を用いた花粉症対 } \\
\text { 策シミレレーション }\end{array}$ \\
\hline & $\begin{array}{l}\text { 伊藤忠テクノソ } \\
\text { リューションズ } \\
\text { (森) }\end{array}$ & パンデミックマップ \\
\hline & $\begin{array}{l}\text { NPO 法人 GIS 総 } \\
\text { 合研究所いばら } \\
\text { き }\end{array}$ & $\begin{array}{l}\text { 自治体統合型 GIS と連携した NPO によ } \\
\text { る地域資源活用支援 g-コンテンツサ } \\
\text { ービス試案 }\end{array}$ \\
\hline & ESRIジャパン㑣) & $\begin{array}{l}\text { 道路占用関連業務を利用した図面流通 } \\
\text { システムについて }\end{array}$ \\
\hline & $\begin{array}{l}\text { (社) 全国地質 } \\
\text { 調查業協会連合 } \\
\text { 会情報化委員会 } \\
\end{array}$ & $\begin{array}{l}\text { 地図を介したコミュニティサイト 地 } \\
\text { 盤情報編 }\end{array}$ \\
\hline & $\begin{array}{l}\text { (有) 空間デー } \\
\text { タサービス }\end{array}$ & $\begin{array}{l}\text { 基盤空間データの為の情報収集更新プ } \\
\text { ロジェクト }\end{array}$ \\
\hline
\end{tabular}

はサービス利用の可能性がある旨や，利用だけではなく 民間データの販売ルートとしてのプラットフォームの利 用可能性の回答が非常に多かった．また，デー夕提供者 のアンケートからは，利用者限定の可能性については

「今後もメンバーの事前登録を継続し，ダウンロード可 能な利用者を限定した方がよい」という回答や，利用許 諾のタイミングとして「今後もダウンロード後でもよい ので，利用者を確認する必要がある」という，現在のサ 一ビス内容を概ね妥当とする回答が多かった点からも現 実的であったと言える.

\section{(9) 残された課題}

最後にアンケートなどの意見もふまえ残された課題 をまとめる。まずデータに関する課題を表-14にまとめ た．主にはデータ提供者とデータ管理者に関わる事項が ある．管理者に関わる事項はやや技術的な点が多く， Webコンテンツなどの作成・管理を効率的に扱うCMS

(Contents Management System) などの仕組みを参考に, 自主的な検討によって解決できるように思える，一方で， 提供者に関わる事項，とくにすでに有償でデータを提供 しているケースや，どの程度の利用を許諾しているかを 明記する，という点については，利用者の意見や，管理 者側への貸与依頼時の細かい調整・交渉等が必要となる ため, 本質的にも重要なことである.

一方で，データほど本質的ではないが，今回のシステ ムに関する課題についても対応の負担が重いと思われる 順に表-15にまとめた。 とくに，「多様なデータの処 理」では，国のデータについては同一仕様であることが ほとんどであるが，都道府県についてはばらばらである ことが多い，例えば今回入手したボーリングや森林情報 などもばらばらであり，登録の処理は相当な負担であっ た。ある程度ばらばらであっても，登録負担量がはっき りするように，データの品質を類型化することは今後と も重要である. また「大容量データの扱い」に関して, 航空写真や電子納品成果では，サイズ，数量ともに大き いものは1県あたりで数十〜数百Gになることも多く, かなりの登録負担になる。こうしたものは今回のような 無償実験にはなじまないものの，コストがかかるという 理由で登録しないことにすると，データの広がりが失わ れてしまう。こうしたデータについても実費ベースで対 応できることが望まれる．また，利用者側のブラウザに ついては，コスト削減の観点からシステム入れ替えのス ピードがそれほど速くない企業や行政などではブラウザ がIE6レベルのことがよくある。これは最近のIE6はサー ビス対象外とする流れと反することもあり，Webコンテ ンツの独自対応が必要となるため, 負担となる. 
表-14 データに関する課題

\begin{tabular}{|c|c|c|}
\hline 分類 & 項目 & 具体内容 \\
\hline \multirow{2}{*}{$\begin{array}{l}\text { 主に提僙 } \\
\text { 者に関利 } \\
\text { る事項 }\end{array}$} & $\begin{array}{l}\text { 提供行為の位置づけ } \\
\text { の明確化 }\end{array}$ & $\begin{array}{l}\text { 今回は地理空間情報に関係する部署への依頼文送付と総務部門への情報公開請求を行ったが，関係部署への依 } \\
\text { 頼がよい結果を生むことがわかった. ただし，地域に協義会が存在し，有償でデータ提供を行っている場合に } \\
\text { ごのように対応するのがよいかは今後の検討課題である. }\end{array}$ \\
\hline & $\begin{array}{l}\text { 利用者から見た場合 } \\
\text { のデータの権利関係 } \\
\text { の明確化 }\end{array}$ & $\begin{array}{l}\text { 今回の実験では, 基本的に, 実データは提供者, メタデータは事務局側に帰属すると想定した. 一部の実デ一 } \\
\text { タは事務局で加工している. 利用者からはクリエイティブコモンズのような使いやすい権利設定が望まれるな } \\
\text { どの声もあった. }\end{array}$ \\
\hline \multirow{5}{*}{$\begin{array}{l}\text { 主に管理 } \\
\text { 者に関护 } \\
\text { る事項 }\end{array}$} & $\begin{array}{l}\text { リンクのみの扱いの } \\
\text { 明確化 }\end{array}$ & $\begin{array}{l}\text { 今回は実データ流通に重点を置いたため, データ提供元へのリンクのみの登録を積極的に行ってこなかった } \\
\text { が, 今後の位置づけを明確にする必要がある. ただしリンクが更新されることが多いため, 対応策も含めて検 } \\
\text { 討が必要である. }\end{array}$ \\
\hline & $\begin{array}{l}\text { データ登録に関する } \\
\text { 有償範囲の明確化 }\end{array}$ & データ量が膨大で加工にかなり手間がかかる場合のコスト負担をどうするかが検討課題である. \\
\hline & $\begin{array}{l}\text { メタデータ定義の明 } \\
\text { 確化 }\end{array}$ & $\begin{array}{l}\text { データ作成者, データ加工者, データ登録者などを中心に, メタデータの解釈にぶれがあり, 適切な情報が登 } \\
\text { 録されない場合があったので再精査が必要である. }\end{array}$ \\
\hline & $\begin{array}{l}\text { 民間データの扱いの } \\
\text { 明確化 }\end{array}$ & $\begin{array}{l}\text { 今回は対象外としたが今後, それぞれのデータ品質を明示しながら同じフレームで流通させることも検討が必 } \\
\text { 要である. }\end{array}$ \\
\hline & 登録頻度の増加 & データ登録の連絡について2週間に一回程度定期的にできるようにし, データ流通量を確保する. \\
\hline
\end{tabular}

表-15 システムに関する課題（対応の負担が重いと思われる順に記載）

\begin{tabular}{|c|c|}
\hline 題目 & 題内容 \\
\hline 多様なデータの処理 & $\begin{array}{l}\text { 今回は，データ種類ごとに個別に登録処理の検討を行ったが，同じ種類のデータでも都道府県ごとに違う場合もある } \\
\text { ため, いくつかのケスに類型化し，登録処理方法を確立する必要がある. }\end{array}$ \\
\hline 大容量データの扱い & $\begin{array}{l}\text { 画像などはとくにサイズが大きいため（ある県の航空写真では } 1 \text { 枚 } 8 \mathrm{MByte} \times 1.5 \text { 万枚 } \fallingdotseq 110 G B y t e ）, \text { 登録・利用の有償 } \\
\text { 化と併せて検討が必要である. }\end{array}$ \\
\hline 様々なブラウザへの対応 & $\begin{array}{l}\text { 今回は, IE8.0 以降，FireFox3 以降，Chrome で対応していたが，現在はあまり推奨されていない } 1 \text { E6.0などを利用してい } \\
\text { る組織も多く，一部は対応したものの今後とも検討が必要である. }\end{array}$ \\
\hline 実データの形式 & $\begin{array}{l}\text { 今回は, 実データに複数ファイルが存在するケースもあることから圧縮形式を基本としていたが, 解凍に手間がかか } \\
\text { るとの声もあるため, 今後検討が必要. ただし，メタデータ生成との関係も考慮する必要がある. }\end{array}$ \\
\hline 線・面データの扱い & $\begin{array}{l}\text { 今回は, すべて代表点の地点情報としてファイルを扱っているが，1 つの点データに比べるとデータ価值が高いこと } \\
\text { から何らかの差別化を図ることが必要. }\end{array}$ \\
\hline 管理機能の充実 & $\begin{array}{l}\text { 今回は, 必要に応じてログの分析プログラムにかけていたが, 定期的にログを処理・分析し, 結果を Webに上げるこ } \\
\text { とが必要. また, データの収集・提供に関する事務局メールの管理をWebベースで行っていなかっだ，今後情報の } \\
\text { 共有化のためにも管理が必要. }\end{array}$ \\
\hline 提供状況等の可視化 & 今回はできなかったが，提供状況の地図上での可視化などが必要である. \\
\hline 検索機能の充実 & $\begin{array}{l}\text { 一部のメタデータが検索対象に含まれていなかったが，今後検討が必要. また，地図の表示範囲のみでしか検索でき } \\
\text { ないというケースがあったが，今後改良が必要である. }\end{array}$ \\
\hline $\begin{array}{l}\text { 自治体・企業等, 組織単 } \\
\text { 位での } \mathrm{D} \text { 発行方法 }\end{array}$ & $\begin{array}{l}\text { 今回は, コンソーシアムへの参加申請を法人単位で， } \mathrm{D} \text { 発行はユーザ単位で行い，紙とメールでの申請が必要となつ } \\
\text { たが，今後， DDの発行単位の検討を含め, Webでの申請に一本化する必要がある. }\end{array}$ \\
\hline パスワードの変更 & パスワード変更の画面を用意していなかったため, 事務局に問い合わせが多く, 今後対応が必要. \\
\hline
\end{tabular}

\section{5. まとめ}

本研究では, サステナブルな地理空間情報流通に 向けた関係者のインセンティブと負担に関する実証 研究として, 地理空間情報の収集・配信・利活用等 の流通環境の整備を目的とした，「地理空間情報流 通実験コンソーシアム」を設立して実証実験を行い, システムを構築するとともに，一般募集した会員向 けにデータ提供サービスを実施し，多くのことを明 らかにした。こうした様々な主体の異なる種類のデ 一タを全国規模で収集し，多数のユーザーで共有し た例は今までなく，大きなインパクトを与えたと言 える。また一方で，データ提供・管理に関して負担 が大きい項目があることも明らかになった．英米に おけるオープンガバメントのサイトに登録されてい るデータセットの数は今や数百〜数千のレベルであ り，我々の取組の十〜百倍の数量である。こうした 規模のものを扱うためには，上述の課題の一つ一つ
を日夜改善していく必要があるが，実験コンソーシ アムを発展的に引き継ぎ，今後とも持続安定的な形 で実証的な研究を進めていきたい.

謝辞：本研究は，検討の過程で東京大学空間情報科 学研究センターで「地理空間情報流通実験コンソー シアム」を開催し，幹事委員や一般委員，多くのデ 一夕提供機関の皆様から有益な御意見を多数頂いた。 感謝したい。また，建設技術研究開発助成制度「地 理空間情報の流通プラットフォーム技術開発による 建設生産プロセスの効率化」というテーマで支援を 頂いた。評価委員・事務局の皆様には感謝したい. また, 東京大学空間情報科学研究センター寄付研究 部門「空間情報社会研究イニシアティブ」の地理空 間情報プラットフォームタスクフォースメンバーに も3年間の協力を頂いた。 感謝したい. 


\section{付録}

注1) 例えば，ITS Japan：安全・環境に資する走行支援严 一ビス実現のための道路情報整備と流通へ向けた提言, 2008. http://www.its-jp.org/wp-content/uploads/2010/09/2d24 1ee556cc6bcfb250a3130e642658.pdf（アクセス：2011年10 月26日）

注2) 政府広報オンライン「新たな公による地域づく り」: http://www.gov-online.go.jp/pr/theme/aratanaooyani_ chiikidukuri.html（アクセス：2011年10月26日）

注3) 国土交通省国土政策局：地理空間情報の二次利用促 進に関するガイドライン， 2010.

http://www.cas.go.jp/jp/seisaku/sokuitiri/220901/honbun02.pdf （アクセス：2011年10月26日）

注4) ティム・バーナーズ・リー : "The year open data went worldwide" : http://www.ted.com/talks/lang/en/tim_berners_l ee_the_year_open_data_went_worldwide.html（アクセス : 2011年10月26日）

注5) 東京大学空間情報科学研究センター：地理空間情報 流通実験コンソーシアム活動報告書, 2011. http://parma.cs is.u-tokyo.ac.jp/GIS/download/GsiConsortiumDoc_v1.3.pdf (アクセス：2011年10月26日)

\section{参考文献}

1) 小林亘, 小原弘志，橋本裕也，成田一真：社会資本 管理のための空間情報連携共通プラットフォームの 構築に関する研究，土木学会土木情報利用技術論文 集, Vol.17, pp.257-262, 2008.

2）橘悠希子，山後公二，湯通堂亨，小原弘志，菅富美 男，梶川昌三，田中大和，飯田洋，島田信也，関本 義秀，今井龍一：地理空間情報プラットフォームに よる行政情報の共有, 地球惑星科学連合連合大会, 2010.

3) 佐藤郁, 渡邊英一, 古田均, 宮口智樹 : マルチエー ジェントによる建設情報データベース統合化に関す る研究，土木学会論文集 F, Vol. 62, No. 1, pp. 13-24,
2006.

4）今井龍一，青山憲明，金澤文彦，上坂克己，大石龍 太郎，櫻井和弘，柴崎亮介：電子納品を導入した公 共事業を対象にした業務プロセス改善の可視化手法 の実証的研究, 土木学会論文集 F, Vol. 64, No. 2, pp. 185-199, 2008.

5）杉森純子，今井龍一，落合修，山口章平，黒岩剛史， 関本義秀，南佳孝，柴崎亮介：地理空間情報の利用 に関する産業界ニーズ調査, 地理情報システム学会 学術研究発表大会, Vol. 18 (CD-ROM), 2009.

6) 薄井智貴, 関本義秀, 金杉洋, 南佳孝, 柴崎亮介： 地理空間情報活用推進に向けた流通実験システムの 開発と適用，土木学会土木情報利用技術論文集，Vol. 19, pp. 125-132, 2010.

7) 中條覚, 関本義秀, 南佳孝, 柴崎亮介：道路更新情 報に関するニーズと情報提供の実態について，第 29 回交通工学研究発表会論文集, pp. 305-308, 2009.

8) 南佳孝, 関本義秀, 中條覚, 柴崎亮介：路線情報を 加味した道路関連情報の位置特定に関する研究，土 木学会論文集 F3（土木情報学）, Vol. 67, No. 1, pp. 7-17, 2011.

9) 清水昇, 三島和恵, 山口章平, 津田宏, 条照宣 : Linked Data と地理空間情報, 情報処理, Vol. 52, No. 3, pp. 318-325, 2011.

10）布施孝志, 松林豊, 中條覚, 高橋香織, 脇嶋秀行, 山口章平 : 公示情報に基づく道路更新情報のクロー リングシステムの検討, 土木情報利用技術論文集, Vol. 18, pp. 281-290, 2009.

11) 関本義秀, 中條覚, 南佳孝, 山口章平, 山田晴利, 布施孝志：工事発注見通し情報を用いた全国におけ る道路更新情報の自動抽出に向けた試み, 土木学会 論文集 D3（土木計画学）, Vol. 68, No. 3, pp. 117-128, 2012.

(2012. 2.8 受付)

\section{EXPERIMENTAL STUDY OF STAKEHOLDERS' INCENTIVE AND BURDEN FOR SUSTAINABLE GEOSPATIAL INFORMATION DISTRIBUTION}

\section{Yoshihide SEKIMOTO, Tomotaka USUI, Harutoshi YAMADA, Ryuichi IMAI, Syohei YAMAGUCHI and Ryosuke SHIBASAKI}

Various applications using geospatial information has been developed by "NSDI Act of Japan" legislated in 2007. However, It is time-consuming matter for usual people to collect fundamental information about national land and public facility, because they are various about format, right, updating frequency, etc. depending each national/local government.

In this research, our objective is to realize smooth data distribution environment about collection, provision, utilization of geospatial information. Specifically we clarify needs of data users and constraints of data holders, and suggest sharing roles of stakeholders through the "Geospatial Information Distribution Experiment Consortium”. In this experimental study, we actually collect various kinds of data all over Japan, develop and operate system sharing these data, aggregate opinions through questionnaire, and evaluate the framework of the data distribution. 